Brazilian Journal

of Chemical

ISSN 0104-6632

Printed in Brazil

Engineering

www.scielo.br/bjce

Vol. 35, No. 02, pp. 459- 466, April - June, 2018

dx.doi.org/10.1590/0104-6632.20180352s20160575

(cc) BY

\title{
PRODUCTION OF CELLULOLYTIC ENZYMES BY GELATOPORIA SUBVERMISPORA USING DIFFERENT SUBSTRATES
}

\author{
Cristiane Bianchi Loureiro ${ }^{1}$, Juliana Machado Gasparotto ${ }^{2}$, Caroline \\ M. Rabuscke ${ }^{1}$, Daiana Bortoluzzi Baldoni ${ }^{1}$, Jerson V. Carús Guedes ${ }^{3}$, \\ Marcio A. Mazutti ${ }^{2, *}$ and Rodrigo J. Seminoti Jacques ${ }^{1, *}$ \\ ${ }^{1}$ Department of Soil Science, Federal University of Santa Maria. Av. Roraima, 1000 - Santa \\ Maria, CEP: 97105-900, Brazil. \\ ${ }^{2}$ Department of Chemical Engineering, Federal University of Santa Maria. Av. Roraima, 1000 \\ - Santa Maria, CEP: 97105-900, Brazil. \\ ${ }^{3}$ Department of Fitossanitary Defense, Federal University of Santa Maria. Av. Roraima, 1000 - \\ Santa Maria, CEP: 97105-900, Brazil.
}

(Submitted: October 5, 2016; Revised: December 5, 2016; Accepted: February 13, 2017)

\begin{abstract}
In this study the solid-state fermentation for production of cellulolytic enzymes by the fungus Gelatoporia subvermispora was optimized. The enzyme activities on filter paper, exo-cellulase, endo-cellulase and xylanase were determined. A Plackett-Burman design (PB) was used to determine the most significant variables (moisture content of substrate, inoculum density, corn steep liquor concentration, $\mathrm{pH}$ and peptone concentration) in the enzyme production for each substrate (sugarcane bagasse, sewage sludge and rice straw). The highest value for filter paper activity was obtained using sugarcane bagasse as substrate. The sewage sludge was an excellent medium for the production of xylanase and exo-cellulases. The endo-cellulase activity was similar in all substrates tested. This is the first report of the Gelatoporia genus for the production of cellulolytic enzymes, being a promising strain for this purpose.
\end{abstract}

Keywords: Pampa biome; Cellulases; Lignocellulosic wastes; Solid state fermentation

\section{INTRODUCTION}

The new concept of ethanol (or bioethanol) production corresponds to utilizing lignocellulosic biomass such as low-cost agricultural, forest residues and wood process wastes (Sims et al., 2008). The conversion of lignocellulosic biomass into fuels can be achieved using enzyme systems acting in order to hydrolyze biomass to glucose. It is well established that hydrolytic efficiency is a result of the synergistic actions of multicomponent enzymatic systems, containing at least three major groups of enzymes: endo-glucanases (E.C. 3.2.1.4), which hydrolyze the cellulose polymer internally, exposing reducing and non-reducing ends; exo-glucanases or cellobiohydrolases (E.C. 3.2.1.91), which act on the reducing and non-reducing ends, releasing cellobiose and cellooligosaccharides; and $\beta$-glucosidases (E.C. 3.2.1.21), which cleave cellobiose, liberating two molecules of glucose-the end product (Maeda et al., 2011; Delabona et al., 2013; Gottschalk et al., 2010).

*Corresponding author: rodrigo@ufsm.br (R. J. S. Jacques), Tel.: +55-55-32208108; mazutti@ufsm.br (M.A. Mazutti), Tel.: +55-55-32209592 branch 30 
The use of cellulase-producing microorganisms and the development of new technological routes for cellulase production remain a strategic issue to be considered during the development of a sustainable process for ethanol production from biomass (Pirota et al., 2016; dos Reis et al., 2015; Juturu and $\mathrm{Wu}, 2014)$. The bioprospection of microorganisms in natural environments able to produce the cellulolytic enzymes is a way to select promising new strains for bioethanol production (Macedo et al., 2013). In this way, Brazil has several biodiversity hot spots, which were not studied, particularly with regard to the diversity of soil microorganisms. Nevertheless, many Latino biomes are under intense process of degradation and loss of biodiversity. So many microorganisms with biotechnological potential are being extinct without at least being known and preserved.

Aiming to reduce this lack of information, collections of cellulolytic fungiwere made in the Pampa biome, located in southern Brazil, which resulted in the first report of the occurrence of Gelatoporia subvermispora in Latin America (Baldoni, 2012). The use of this fungus for cellulolytic enzyme production is unknown. Therefore, the aim of this study was to evaluate production of cellulolytic enzymes by solidstate fermentation using the fungus $G$. subvermispora. Different lignocellulosic wastes (sugarcane bagasse, sewage sludge and rice straw) were used as substrates for the fermentations.

\section{MATERIALS AND METHODS}

\section{Microorganism}

Gelatoporia subvermispora was first isolated from the Brazilian Pampa biome in a pine forest by Baldoni (2012). Stock cultures of G. subvermispora were propagated on potato dextrose agar (PDA) using Petri plates at $28^{\circ} \mathrm{C}$ for five days.

\section{Solid substrates}

Sugarcane bagasse was obtained in a micro distillery for bioethanol production and rice straw was obtained from a rice processing industry. In the laboratory, the residues were dried at $60^{\circ} \mathrm{C}$ during 24 hours, grounded in a cutting mill and sieved with a final particle size of 8 mesh. The collection of the activated sludge occurred in November, 2012, in a domestic sludge treatment plant, in the drying beds with longer discharge (approximately 90 days) in order to collect more stabilized sludge. The sewage sludge was dried in an oven with forced air circulation (Brand New Ethics 420 model - 5D) at $40^{\circ} \mathrm{C}$ for seven days. The dry material was homogenized in a mill and sieved in 2 mesh. The solid substrate for enzyme production was composed of sugarcane bagasse or rice straw or sewage sludge as the main carbon source, supplemented with peptone and corn steep liquor.

\section{Production of cellulolytic enzymes and their assays}

Plackett-Burman design (PB) was used to determine the best conditions in the enzyme production by solid state fermentation. The evaluated variables were moisture content of substrate (60 to $80 \%$ ), inoculum density ( 1 to 3 mycelium discs of 3 $\mathrm{mm}$ ), corn steep liquor ( 0 to $15 \% \mathrm{v} / \mathrm{w}), \mathrm{pH}$ (5 to 7 ) and peptone concentration ( 5 to $20 \mathrm{wt} \%$ ). A PB design composed of twelve runs plus three central points was accomplished for each substrate (sugarcane bagasse, rice straw and sewage sludge). Table 1 presents the investigated range for each variable in the three PB designs.

Table 1: Matrix of Plackett and Burman design employed to determine the best conditions for cellulolytic enzyme production by Gelatoporia subvermispora using different substrates.

\begin{tabular}{cccccc}
\hline Run & $\mathbf{p H}$ & $\begin{array}{c}\text { Peptone } \\
\text { (wt\%) }\end{array}$ & $\begin{array}{c}\text { Moisture } \\
\text { (wt\%) }\end{array}$ & $\begin{array}{c}\text { CSL* } \\
\text { (wt\%) }\end{array}$ & $\begin{array}{c}\text { Inoculum } \\
\text { (wt\%) }\end{array}$ \\
\hline $\mathbf{1}$ & $(+1) 7$ & $(-1) 5$ & $(+1) 80$ & $(-1) 0$ & $(-1) 1$ \\
$\mathbf{2}$ & $(+1) 7$ & $(+1) 20$ & $(-1) 60$ & $(+1) 15$ & $(-1) 1$ \\
$\mathbf{3}$ & $(-1) 5$ & $(+1) 20$ & $(+1) 80$ & $(-1) 0$ & $(+1) 3$ \\
$\mathbf{4}$ & $(+1) 7$ & $(-1) 5$ & $(+1) 80$ & $(+1) 15$ & $(-1) 1$ \\
$\mathbf{5}$ & $(+1) 7$ & $(+1) 20$ & $(-1) 60$ & $(+1) 15$ & $(+1) 3$ \\
$\mathbf{6}$ & $(+1) 7$ & $(+1) 20$ & $(+1) 80$ & $(-1) 0$ & $(+1) 3$ \\
$\mathbf{7}$ & $(-1) 5$ & $(+1) 20$ & $(+1) 80$ & $(+1) 15$ & $(-1) 1$ \\
$\mathbf{8}$ & $(-1) 5$ & $(-1) 5$ & $(+1) 80$ & $(+1) 15$ & $(+1) 3$ \\
$\mathbf{9}$ & $(-1) 5$ & $(-1) 5$ & $(-1) 60$ & $(+1) 15$ & $(+1) 3$ \\
$\mathbf{1 0}$ & $(+1) 7$ & $(-1) 5$ & $(-1) 60$ & $(-1) 0$ & $(+1) 3$ \\
$\mathbf{1 1}$ & $(-1) 5$ & $(+1) 20$ & $(-1) 60$ & $(-1) 0$ & $(-1) 1$ \\
$\mathbf{1 2}$ & $(-1) 5$ & $(-1) 5$ & $(-1) 60$ & $(-1) 0$ & $(-1) 1$ \\
$\mathbf{1 3}$ & $(0) 6$ & $(0) 12,5$ & $(0) 70$ & $(0) 7,5$ & $(0) 2$ \\
$\mathbf{1 4}$ & $(0) 6$ & $(0) 12,5$ & $(0) 70$ & $(0) 7,5$ & $(0) 2$ \\
$\mathbf{1 5}$ & $(0) 6$ & $(0) 12,5$ & $(0) 70$ & $(0) 7,5$ & $(0) 2$ \\
\hline
\end{tabular}

*Corn steep liquor. 
The fermentations were carried out in conical flasks $(500 \mathrm{~mL})$ containing $10 \mathrm{~g}$ of the respective solid substrate. Afterwards, the solid substrates were supplemented with peptone and corn steep liquor and the moisture content adjusted at the specified level. Each flask was covered with hydrophobic cotton and autoclaved at $121^{\circ} \mathrm{C}$ for $20 \mathrm{~min}$. After cooling, each flask was inoculated with mycelium discs $(3 \mathrm{~mm}$ diameter) and incubated for $120 \mathrm{~h}$ at $28^{\circ} \mathrm{C}$ for five days. The cellulolytic enzymes considered in this work were filter paper activity (FPU.g ${ }^{-1}$ ), exo-cellulase activity $\left(\mathrm{U} \cdot \mathrm{g}^{-1}\right)$, endo-cellulase activity $\left(\mathrm{U} \cdot \mathrm{g}^{-1}\right)$ and xylanase activity $\left(\mathrm{U} \cdot \mathrm{g}^{-1}\right)$.

\section{Extraction of the cellulolytic enzymes and assays}

At the end of fermentation, the cellulolytic enzymes were extracted using $100 \mathrm{~mL}$ of $50 \mathrm{mM}$ sodium acetate buffer ( $\mathrm{pH} 4.8$ ) in an orbital shaker at $120 \mathrm{rpm}$ and $28^{\circ} \mathrm{C}$ during 1 hour. Afterwards, $30 \mathrm{~mL}$ of the enzyme extract was withdrawn for determination of enzyme activities.

Cellulolytic enzyme activities were determined as described by Ghose (1987), with few modifications. The filter paper activity assay was carried out using $50 \mathrm{mg}$ of Whatmann $\mathrm{n}^{\circ} 1$ filter paper, $1 \mathrm{~mL}$ of diluted enzyme extract, $2 \mathrm{~mL}$ of $50 \mathrm{mM}$ sodium acetate buffer ( $\mathrm{pH} \mathrm{4.8),} \mathrm{and} \mathrm{the} \mathrm{mixture} \mathrm{was} \mathrm{incubated} \mathrm{for} 60 \mathrm{~min}$ at $50^{\circ} \mathrm{C}$. It is important to point out that filter paper presents amorphous and crystalline cellulose in a manner that filter paper activity can be related to the total cellulolytic activity of the extract. Exo-cellulase activities were determined using $50 \mathrm{mg}$ of sigmacell cellulose type $20(20 \mu \mathrm{m}$, microcrystalline cellulose, Sigma Aldrich), $1 \mathrm{~mL}$ of diluted enzyme extract and $2 \mathrm{~mL}$ of $50 \mathrm{mM}$ sodium acetate buffer $(\mathrm{pH} \mathrm{4.8)}$. The mixture was incubated for $5 \mathrm{~min}$ at $40^{\circ} \mathrm{C}$. Endocellulase activities were measured using $1 \mathrm{~mL}$ of diluted enzyme extract in $2 \mathrm{~mL}$ of a $\%$ carboxymethyl cellulose (Sigma Aldrich) in a $50 \mathrm{mM}$ acetate buffer ( $\mathrm{pH} 4.8$ ), and the reaction were carried out at $50^{\circ} \mathrm{C}$ during $30 \mathrm{~min}$. Xylanase activities were measured by adding $0.3 \mathrm{~mL}$ of diluted enzyme and $2.7 \mathrm{~mL}$ of a $1 \%$ beach wood xylan (Sigma Aldrich) solution in $10 \mathrm{mM}$ phosphate buffer (pH 5.2), and incubating for $5 \mathrm{~min}$ at $50^{\circ} \mathrm{C}$. For all enzyme activity measurements, a standard without substrate was carried out to subtract the initial amount of reducing sugars (RS). Reducing sugars were measured by the spectrophotometric DNS method, using glucose as standard for FPU, exo-cellulases and endo-cellulases, whereas xylose was used as standard for xylanase activity. In all cases the absorbances of samples were measured at $540 \mathrm{~nm}$ (Miller, 1959). One unit of enzyme activity was defined as the amount of enzyme which forms $1 \mu \mathrm{mol}$ of glucose or xylose per min under the assay conditions.

\section{Statistical analysis}

All the results were analyzed using the software Statistica ${ }^{\circledR} 7.0$ (Statsoft Inc., Tulsa, OK, USA), considering a significance level of $90 \%$.

\section{RESULTS AND DISCUSSION}

Table 2 presents the results obtained in the three PB designs to investigate the production of cellulolytic enzymes using sewage sludge, rice straw and sugarcane bagasse as substrates. The highest values for filter paper activity were obtained using sugarcane bagasse as substrate, whereas sewage sludge was not a good support medium for production of extracts with high filter paper activities. However, sewage sludge was an excellent medium for production of extracts with high exo-cellulase and xylanase activities. The production of cellulolytic enzymes with endo-cellulase activities was similar in all substrates tested. For run 11 in rice straw substrate and run 14 in sewage sludge substrate endo-cellulase activities were observed of $40.75{\mathrm{U} . \mathrm{g}^{-1}}^{-1}$

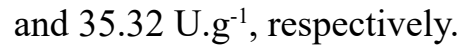

Data of Table 2 were used to compute the main effects of the independent variables on the production of each cellulolytic enzyme for the three substrates used and the results are presented in Table 3. Using rice straw as substrate, the moisture content influenced significantly the production of the cellulolytic enzymes with filter paper and xylanase activities, both negatively. The production of enzymes with exocellulase activities was influenced negatively by CSL and inoculum density. On the other hand, the inoculum density presented a positive effect on production of enzymes with xylanase activities. Using sewage sludge as substrate, none of the variables investigated was statistically significant in the evaluated range. Using sugarcane bagasse, CSL presented a negative effect on the production of enzymes with filter paper activity, whereas $\mathrm{pH}$ showed positive effects on the production of xylanase.

From the analysis of effects and data of Table 2 , it is evident that, depending on the experimental condition used, the enzyme produced can present a specific activity. In recent years, there is a growing interest in cellulases to hydrolyze cellulose for bioethanol 
Table 2: Results obtained in the PB design to evaluate the production of cellulolytic enzymes by solid-state fermentation in different solid substrates.

\begin{tabular}{|c|c|c|c|c|c|c|c|c|c|c|c|c|}
\hline \multirow[b]{2}{*}{$\operatorname{Exp}$} & \multicolumn{4}{|c|}{ Rice straw } & \multicolumn{4}{|c|}{ Sewage sludge } & \multicolumn{4}{|c|}{ Sugarcane bagasse } \\
\hline & R1 & $\mathbf{R 2}$ & $\mathbf{R 3}$ & R4 & $\mathbf{R 1}$ & $\mathbf{R 2}$ & $\mathbf{R 3}$ & R4 & $\mathbf{R 1}$ & $\mathbf{R 2}$ & R3 & R4 \\
\hline 1 & 0.00 & 25.45 & 14.06 & 0.44 & 0.07 & 118.45 & 16.83 & 0.88 & 1.14 & 6.69 & 143.79 & 1.33 \\
\hline 2 & 0.21 & 18.53 & 33.93 & 0.66 & 0.07 & 113.88 & 20.36 & 2.90 & 0.40 & 107.17 & 55.15 & 0.00 \\
\hline 3 & 0.06 & 24.49 & 10.60 & 0.83 & 0.05 & 74.81 & 18.49 & 3.06 & 0.33 & 4.46 & 21.54 & 0.89 \\
\hline 4 & 0.02 & 13.28 & 1.45 & 1.06 & 0.17 & 70.45 & 72.32 & 0.51 & 0.15 & 0.00 & 13.95 & 1.73 \\
\hline 5 & 0.10 & 3.12 & 57.27 & 1.50 & 0.13 & 65.15 & 227.97 & 0.46 & 0.61 & 21.65 & 44.54 & 1.28 \\
\hline 6 & 0.10 & 24.89 & 9.93 & 0.61 & 0.09 & 78.03 & 206.57 & 0.41 & 0.34 & 3.34 & 77.14 & 0.16 \\
\hline 7 & 0.10 & 16.52 & 1.00 & 0.89 & 0.28 & 126.14 & 51.85 & 1.24 & 0.30 & 39.52 & 21.99 & 0.61 \\
\hline 8 & 0.15 & 12.50 & 12.39 & 1.50 & 0.00 & 100.79 & 35.84 & 0.20 & 0.39 & 3.57 & 21.43 & 0.55 \\
\hline 9 & 1.06 & 4.01 & 71.67 & 0.83 & 0.00 & 117.73 & 36.16 & 0.83 & 0.09 & 100.47 & 27.24 & 2.56 \\
\hline 10 & 0.49 & 13.50 & 104.38 & 1.33 & 0.07 & 82.40 & 21.92 & 0.20 & 1.38 & 6.69 & 24.22 & 4.35 \\
\hline 11 & 0.46 & 143.45 & 0.00 & 40.75 & 0.06 & 134.25 & 22.75 & 0.77 & 0.33 & 40.19 & 23.44 & 1.84 \\
\hline 12 & 0.31 & 75.24 & 0.89 & 0.27 & 0.00 & 61.61 & 15.58 & 0.15 & 3.82 & 19.98 & 9.15 & 4.52 \\
\hline 13 & 0.08 & 43.23 & 10.22 & 0.72 & 0.08 & 97.30 & 4.11 & 28.26 & 0.62 & 8.57 & 28.24 & 0.74 \\
\hline 14 & 0.09 & 34.47 & 13.50 & 0.61 & 0.07 & 93.30 & 4.36 & 35.32 & 0.63 & 8.93 & 25.56 & 0.63 \\
\hline 15 & 0.10 & 36.07 & 11.94 & 0.68 & 0.06 & 99.49 & 5.05 & 30.05 & 0.61 & 8.93 & 22.55 & 0.69 \\
\hline
\end{tabular}

$\mathrm{R} 1=$ Filter paper activity $\left(\mathrm{U} . \mathrm{g}^{-1}\right) ; \mathrm{R} 2=$ Exo-cellulases activity $\left(\mathrm{U} . \mathrm{g}^{-1}\right) ; \mathrm{R} 3=$ Xylanases activity $\left(\mathrm{U}^{-\mathrm{g}^{-1}}\right) ; \mathrm{R} 4=$ Endo-cellulases activity $\left(\mathrm{U} . \mathrm{g}^{-1}\right)$

Table 3: Effects of independent variables on the activities of cellulolytic enzymes produced by solid-state fermentation using rice straw, sewage sludge and sugarcane bagasse as substrates.

\begin{tabular}{|c|c|c|c|c|c|c|c|c|}
\hline & \multicolumn{2}{|c|}{ Filter paper activity } & \multicolumn{2}{|c|}{ Exo-cellulase activity } & \multicolumn{2}{|c|}{ Xylanase activity } & \multicolumn{2}{|c|}{ Endo-cellulase activity } \\
\hline & Effect & p-value & Effect & p-value & Effect & p-value & Effect & p-value \\
\hline & \multicolumn{8}{|c|}{ Rice straw } \\
\hline pH & -0.20 & 0.1325 & -29.57 & 0.0818 & 20.75 & 0.1038 & -6.58 & 0.2734 \\
\hline Peptone & -0.17 & 0.2082 & 14.50 & 0.3618 & -15.35 & 0.2133 & 6.63 & 0.2695 \\
\hline Moisture & -0.37 & 0.0154 & -23.45 & 0.1547 & -36.45 & 0.0112 & -6.67 & 0.2673 \\
\hline CSL & 0.04 & 0.7723 & -39.84 & 0.0269 & 6.31 & 0.5955 & -6.30 & 0.2930 \\
\hline \multirow[t]{2}{*}{ Inoculum } & 0.14 & 0.2736 & -34.99 & 0.0456 & 35.82 & 0.0122 & -6.24 & 0.2968 \\
\hline & \multicolumn{8}{|c|}{ Sewage sludge } \\
\hline pH & 0.03 & 0.3381 & -14.49 & 0.5224 & 64.22 & 0.1010 & -0.15 & 0.9839 \\
\hline Peptone & 0.06 & 0.1084 & 6.81 & 0.7618 & 58.22 & 0.1320 & 1.01 & 0.8904 \\
\hline Moisture & 0.06 & 0.1464 & -1.06 & 0.9623 & 9.53 & 0.7925 & 0.17 & 0.9821 \\
\hline CSL & 0.05 & 0.1695 & 7.43 & 0.7408 & 23.73 & 0.5167 & 0.11 & 0.9879 \\
\hline \multirow[t]{2}{*}{ Inoculum } & -0.05 & 0.1695 & -17.65 & 0.4387 & 57.88 & 0.1341 & -0.21 & 0.9766 \\
\hline & \multicolumn{8}{|c|}{ Sugarcane bagasse } \\
\hline pH & -0.21 & 0.6612 & -10.44 & 0.6705 & 39.00 & 0.0645 & -0.35 & 0.7328 \\
\hline Peptone & -0.78 & 0.1228 & 13.16 & 0.5931 & 0.67 & 0.9719 & -1.71 & 0.1225 \\
\hline Moisture & -0.66 & 0.1798 & -39.76 & 0.1284 & 19.35 & 0.3234 & -1.55 & 0.1576 \\
\hline CSL & -0.90 & 0.0799 & 31.84 & 0.2129 & -19.16 & 0.3279 & -1.06 & 0.3183 \\
\hline Inoculum & -0.50 & 0.3014 & -12.23 & 0.6190 & -8.56 & 0.6550 & -0.04 & 0.9691 \\
\hline
\end{tabular}

Bold variables are statistically significant at $90 \%$ of confidence $(\mathrm{p}<0.1)$ 
production. In this scenario, the cellulolytic enzymes should present high filter paper activity since it represents the action of enzyme on amorphous and crystalline cellulose. For this reason, the conditions of runs 9,7 and 12 were considered to be optimal for cellulolytic enzymes production using rice straw, sewage sludge and sugarcane bagasse, respectively, because in these runs the filter paper activities were the highest for each substrate. The filter paper, exocellulase, xylanase and endo-cellulase activities using rice straw as substrate were $1.06 \mathrm{FPU}^{-1}{ }^{-1}, 4.01 \mathrm{U} . \mathrm{g}$ 1, $71.67 \mathrm{U} . \mathrm{g}^{-1}$ and $0.83 \mathrm{U} \cdot \mathrm{g}^{-1}$; for sewage sludge the

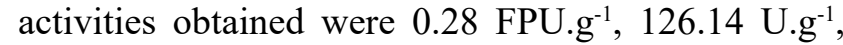
$51.85{\mathrm{U} . g^{-1}}^{-1}$ and $1.24{\mathrm{U} . \mathrm{g}^{-1}}^{-}$; for sugarcane bagasse the activities were 3.82 FPU.g ${ }^{-1}, 19.98{\mathrm{U} . g^{-1}}^{-1} 9.15{\mathrm{U} . g^{-1}}^{-1}$

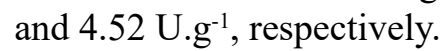

To validate these results, three additional fermentations were carried out at defined conditions for each substrate. The total cellulolytic enzyme estimated by filter paper, exo-cellulase, xylanase and endo-cellulase activities using rice straw as substrate were 0.11 FPU.g ${ }^{-1}, 13.75{\mathrm{U} . g^{-1}}^{-1} 1184.20{\mathrm{U} . g^{-1}}^{1}$ and 1.07 $\mathrm{U.g}^{-1}$; for sewage sludge the activities obtained were

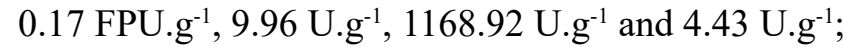
for sugarcane bagasse the activities were $3.43 \mathrm{FPU} . \mathrm{g}^{-1}$,

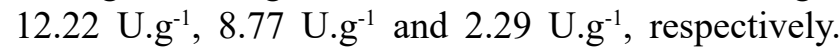
For sugarcane bagasse there is a good agreement with the results presented in Table 2 at run 12, whereas for sludge sewage and rice straw some deviation was verified.

Although there are no studies reporting the production of cellulolytic enzymes by the fungus Gelatoporia subvermispora from sewage sludge, the results obtained here are in good agreement with other authors, where the production occurred from other substrates. In our study, the total cellulolytic activity was very low from rice straw and sewage sludge; a the better result was found from sugarcane bagasse. Similar results were observed in a study conducted by Ferraz et al. (2003) to evaluate the enzymatic activities of Ceriporiopsis subvermispora grown on wood chips under solid-state fermentation, where reducing sugars were detected by incubation of filter paper with the culture extracts. Cellulase levels were very low and did not attain appropriate concentrations to permit determination of filter paper activities based on the standard assay. In the same way, in a study conducted by Souza-Cruz et al. (2004), only small amounts of reducing sugars were detected by incubation of filter paper strips with the extracts of a culture of Ceriporiopsis subvermispora during biopulping of Pinus taeda wood chips. Delignification of corn stover by the white rot fungus Ceriporiopsis subvermispora in solid-state cultivation was evaluated for improving subsequent enzymatic hydrolysis by Wan and $\mathrm{Li}$ (2010). Xylanase was the only enzyme detected and reducing sugars released from the assay mixture by incubation of filter paper strips with enzyme extract were not high enough to determine filter paper activity. Our results are consistent with several reports on cellulolytic activity of $C$. subvermispora cultured on woody biomass.

The xylanase enzymes are responsible for the degradation of hemicellulose polymers. The highest activity for this enzyme found in our study suggests that $G$. subvermispora is able to convert hemicellulose in reducing sugars, such as pentoses and hexoses. According to Ferraz et al. (2003), xylanase was the main hydrolytic activity, reaching its maximum on the 15th day of biodegradation (960 U per culture), although $\beta$-glucosidase activities were also low (21 $\mathrm{U}$ per culture on the 15 th day) as compared to the xylanase activity. In a study conducted by Souza-Cruz et al. (2004), xylanolytic activity of the extract was initially assayed by measuring the amounts of reducing end groups released after birch xylan treatment with the extract. The level of xylanases was $303 \pm 33$ U.L $^{-1}$ of extract, corresponding to $778 \pm 92{\mathrm{U} . \mathrm{kg}^{-1} \text { of wood }}^{-1}$ present in the cultures. Xylanolytic activity found in our study from rice straw and sewage sludge was about 14 times higher per gram of substrate.

In another study three different substrates (wheat straw, pine and poplar wood) were used for producing ligocellulolytic enzymes by Ceriporiopsis subvermispora. The authors found that cellulases activities were very low while xylanases predominated. Wheat straw was the best substrate for production of cellulases using submerged fermentation (4.38 U.mL ${ }^{-1}$ ) and xylanases (23.34 U.mL ${ }^{-1}$ ) (Chmelová and Ondrejovič, 2012). Several hydrolytic enzymes were produced by $C$. subvermispora during solidstate fermentation of Eucalyptus grandis and Pinus taeda wood chips. Xylanase activities recovered from biotreated $P$. taeda (256.7 $\left.\mathrm{U.kg}^{-1}\right)$ were almost twice the activities recovered from $E$. grandis (126.2 ${\left.\mathrm{U} . \mathrm{kg}^{-1}\right)}^{-1}$ (Heidorne et al., 2006). Compared to our study, these results suggest that the xylanolytic activity enzymes produced by G. subvermispora are highly dependent of the substrate used.

In another study cellulase activity was less than $20{\mathrm{U} . \mathrm{kg}^{-1}}$ for wood decayed by C. subvermispora. Xylanase activity was detected only after 15 days of E. globulus biodegradation, $50 \mathrm{U} \cdot \mathrm{kg}^{-1}$ of wood with 15 days and up to $550 \mathrm{U} \cdot \mathrm{kg}^{-1}$ of wood after 60 days 
of biotreatment (Mendonça et al., 2008). The pattern of xylanase reached its peak value of $4.8 \mathrm{U.g}^{-1}$ solid on day 7. The lowest level was observed on day 18 , after which a slight increase in activity followed and the activity reached $4.1{\mathrm{U} . \mathrm{g}^{-1}}$ solid at the end of the fungal pretreatment. The level of xylanase activity in this study was close to that observed from some other solid cultures of $C$. subvermispora. Xylanase activity of 4.5 and 4.3 IU.g $\mathrm{g}^{-1}$ solid was observed from 30 days solid fermentation of sugarcane bagasse and hardwood P. taeda, respectively (Guerra et al., 2003; Costa et al., 2005). The xylanolytic activity depends on the substrate used and in addition there is a large influence of the fermentation time. In our study, the pattern of xylanase reached its peak values of $71.67 \mathrm{U.g}^{-1}$ and 51.85 ${\mathrm{U} . \mathrm{g}^{-1}}^{-1}$ on day 5 , using rice straw and sewage sludge, respectively. As regards their industrial applicability, xylanases have been used in the feed of monogastric animals to hydrolyze nonstarch polysaccharides such as arabinoxylans, and are therefore of interest to the industry of animal feed (Kuhad et al., 2011).

On the other hand, the values found for cellulase activity in the three different substrates suggest that enzyme could be used for many industrial applications. In run 11 a high exo-cellulase (143.45 $\left.\mathrm{U} . \mathrm{g}^{-1}\right)$ and endo-cellulase (40.75 ${\left.\mathrm{U} . \mathrm{g}^{-1}\right)}$ activity was observed using rice straw as substrate; both results have potential for detergent industries. In the patent published by Bjork et al. (1997) a detergent composition containing Trichoderma longibrachiatum exo-cellobiohydrolase I and endoglucanase were added at the ratios of 10:1-400:1 to provide superior cleaning capacity ( $91 \%$ reflectance), imparting high softness to the cloth and reduced tensile strength. The endo-glucanases have a wide spectrum of applications in various industries. The high activity of this enzyme verified in runs $5\left(227.97{\mathrm{U} . g^{-1}}^{-1}\right.$ and $6\left(206.57{\mathrm{U} . g^{-1}}^{-1}\right)$ has potential for food processing industries. Mixtures of endo-glucanases and hemicellulases have also been used for biomodification of fiber properties in paper mills in the beating of pulp (Dienes et al., 2004), because endo-glucanases have the ability to decrease the pulp viscosity with a lower degree of hydrolysis (Pere et al., 1995). Besides the application to obtain bioethanol, enzymes produced by $G$. subvermispora can be used for various biotechnological purposes. Depending on the substrate used in the production, specific enzymes can be enhanced. Furthermore, good results were found from the increase of the scale of production, suggesting that G. subvermispora has the biotechnological potential to produce cellulolytic enzymes in bioreactors.

\section{CONCLUSIONS}

The results obtained in this work allowed concluding that the highest value for the total cellulolytic activity was obtained using sugarcane bagasse as substrate, reaching the value of 3.82 FPU.g ${ }^{-1}$. The sewage sludge was an excellent medium for the production of xylanase and exo-cellulases, reaching peak activities of $227.97{\mathrm{U} . \mathrm{g}^{-1}}^{1}$ and $134.25{\mathrm{U} . \mathrm{g}^{-1}}^{-1}$, respectively. The endocellulase activity was similar in all substrates tested, \left. as shown in the runs 11 for rice straw (40.75 ${\mathrm{U} . \mathrm{g}^{-1}}^{-1}\right)$

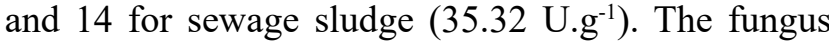
G. subvermispora isolated first in Latin America has the biotechnological potential to produce cellulolytic enzymes in bioreactors.

\section{ACKNOWLEDGEMENTS}

The authors thank the Research Support Foundation of Rio Grande do Sul (FAPERGS), Brazilian National Council for Scientific and Technological Development $(\mathrm{CNPq})$ and Coordination for the Improvement of Higher Education Personnel (CAPES) for the financial support of this work and scholarships.

\section{REFERENCES}

Baldoni, D. B., Ocorrência de Pseudomerullius curtisii, Gelatoporia subvermispora e Sarcoporia polyspora no sul do Brasil. Dissertation, University Federal of Santa Maria (2012).

Bjork, N., Clarkson, K. A., Lad, P. J., and Weiss, G. L., Degradation resistant detergent compositions based on cellulase enzymes. US patent 5688290 (1997).

Chmelová, D., Ondrejovič, M., Ondás, V., and Šturdík, E., Influence of cultivation conditions on production of lignocellulolytic enzymes by Ceriporiopsis subvermispora. Biol., 5, 748-754 (2011).

Chmelová, D., and Ondrejovič, M., Determination of enzymes produced by Ceriporiopsis subvermispora during pretreatment of different biomass sources. J. of Microb. Biotechnol. Food Sci., 4, 1168-1178 (2012).

Costa, S. A., Gonçalves, A. R., and Esposito, E., Ceriporiopsis subvermispora used in delignification of sugarcane bagasse prior to soda/anthraquinone pulping. Appl. Biochem. Biotechnol., 121, 695-706 (2005).

Delabona, P. S., Cota, J., Hoffmam, Z. B., Paixão, D. A., Farinas, C. S., Cairo. J. P., Lima, D. J., Squina, F. M., Ruller, R., and Pradella, J. G., Understanding 
the cellulolytic system of Trichoderma harzianum P49P11 and enhancing saccharification of pretreated sugarcane bagasse by supplementation with pectinase and a-L-arabinofuranosidase. Bioresourc. Technol., 131, 500-507 (2013).

Dienes, D., Egyházi, A., and Réczey, K., Treatment of recycled fiber with Trichoderma cellulases. Ind. Crops Prod., 20, 11-21 (2004).

Ferraz, A., Córdova, A. M., and Machuca, A., Wood biodegradation and enzyme production by Ceriporiopsis subvermispora during solid-state fermentation of Eucalyptus grandis. Enzym. Microb. Technol., 32, 59-65 (2003).

Ghose, T. K., Measurement of cellulase activities. Pure Appl. Chem., 59, 257-268 (1987).

Gottschalk, L. M. F., Oliveira, R. A., and Bom, E. P. S., Cellulases, xylanases, $\beta$-glucosidase and ferulic acid esterase produced by Trichoderma and Aspergillus act synergistically in the hydrolysis of sugarcane bagasse. Biochem. Eng. J., 51, 72-78 (2010).

Guerra,A., Mendonça, R., andFerraz,A., Molecular weight distribution of wood components extracted from Pinus taeda biotreated by Ceriporiopsis subvermispora. Enzym. Microb. Technol., 33, 12-18 (2003).

Heidorne, F. O., Magalhães, P. O., Ferraz, A. L., and Milagres, A. M. F., Characterization of hemicellulases and cellulases produced by Ceriporiopsis subvermispora grown on wood under biopulping conditions. Enzym. Microb. Technol., 38, 436-442 (2006).

Juturu, V., and $\mathrm{Wu}$, J. C., Microbial cellulases: Engineering, production and applications. Renew. Sustain. Energy Rev., 33, 188-203 (2014).

Kuhad, R. C., Gupta, R., and Singh, A., Microbial cellulases and their applications. Enzym. Res., 2011, article ID 280696, 10 pages (2011).

Macedo, E. P., Cerqueira, C. L. O., Souza, D. A. J., Bispo, A. S. R., Coelho, R. R. R., Nascimento, R. P., Production of cellulose-degrading enzyme on sisal and other agro-industrial residues using a new Brazilian actinobacteria strain Streptomyces sp. SLBA-08. Braz. J. Chem. Eng., 30 (4), 729-735 (2013)

Maeda, R. N., Serpa, V. I., Rocha, V.A. L., Mesquita, R. A. A., Santa Anna, L. M. M., Castro, A. M.,
Driemeir, C. E., Pereira Jr., N., and Polikarpov, I., Enzymatic hydrolysis of pretreated sugarcane bagasse using Penicillium funiculosum and Trichoderma harzianum cellulases. Process. Biochem., 46, 1196-1201 (2011).

Mendonça, R. T., Jara, J. F., González, V., Elissetche, J. P., and Freer, J., Evaluation of the white-rot fungi Ganoderma australe and Ceriporiopsis subvermispora in biotechnological applications. J. Ind. Microb. Biotechnol., 35, 1323-1330 (2008).

Miller, G. L., Use of dinitrosalicylic acid and reagent for determination of reducing sugar. Anal. Chem., 31, 426-427 (1959).

Pere, J., Siika-aho, M., Buchert, J., and Viikari, L., Effects of purified T. reesei cellulases on the fiber properties of kraft pulp. Tappi J., 78, 1-78 (1995).

Pirota, R. D. P. B., Tonelotto, M., Delabona, P. S., Fonseca, R. F., Paixão, D. A. A., Baleeiro, F. C. F., Bertucci Neto, V., Farinas, C. S., bioprocess developments for cellulase production by Aspergillus oryzae cultivated under solid-state fermentation. Braz. J. Chem. Eng, 33 (1), 21-31 (2016)

Reis, L., Ritter, C. E. T., Fontana, R. C., Camassola, M., Dillon, A. J. P., Statistical optimization of mineral salt and urea concentration for cellulase and xylanase production by Penicillium echinulatum in submerged fermentation. Braz. J. Chem. Eng., 32 (1), 13-22 (2015)

Sims, R., and Taylor, M., From 1st-to 2nd Generation Biofuel Technologies. An overview of current industry and R\&D activities. Mendeley, Paris (2008).

Souza-Cruz, P. B. de, Freer, J., Siika-Aho, M., and Ferraz, A., Extraction and determination of enzymes produced by Ceriporiopsis subvermispora during biopulping of Pinus taeda wood chips. Enzym. Microb. Technol., 34, 228-234 (2004).

Wan, W., and Li, Y. Microbial delignification of corn stover by Ceriporiopsis subvermispora for improving cellulose digestibility. Enzim. Microb. Technol., 47, 31-36 (2010). 
